\title{
CHEMICAL AND STRUCTURAL CHARACTERIZATION OF SLAG COMPOUNDS FORMED IN THE MELTING PROCESSES TO PRODUCE SPHEROIDAL GRAPHITE CAST IRONS
}

\section{Introduction}

One of the main problems of spheroidal graphite (SG) cast iron production is the formation of slag compounds that can be formed in any of the various stages of the manufacturing process. The consequence of the formation of these slag compounds depends on the stage in which they are formed. Slag inclusions can be found as an inclusion in the manufactured parts, which is one of the most common defects, ${ }^{1,2}$ but they can also be found, as adhered products in the refractory linings of melting furnaces. In this second case, important reductions on the internal diameter of refractory crucibles are detected which decrease the effective capacity of melting furnaces. In addition to this fact, the formation of such slag accumulations causes cracks and erosion in the silica refractory lining and it promotes failures on the inductor isolation systems. ${ }^{3,4}$ The other important source of active slag is the treatment of base melts with magnesium ferroalloys. ${ }^{5}$ These slag techniques were used for analyzing the slag samples: X-ray fluorescence, X-ray diffraction and scanning electron microscopy with EDS microanalysis. Important differences have been detected among samples studied in this work that have revealed the detrimental role of aluminum on refractory linings. The obtained knowledge has been successfully used to minimize the problems caused by adhesion of slags to refractory linings.

Keywords: spheroidal graphite cast irons, slag compounds, induction furnace, refractory lining, X-ray diffraction, $X$-ray fluorescence, scanning electron microscopy

compounds have to be properly removed from ladles in order to minimize subsequent contamination problems on pouring devices used in foundry plants. Otherwise such slag products will be rapidly deposited on the refractory lining, and a high risk of degradation will be present in the pouring tools. In general, filters and/or proper filling systems are commonly used in molds for avoiding the appearance of slag inclusions on castings.

In order to avoid the problems related to the formation of slag, it is important to know its chemical composition and those phases present in the slag compound formed at different stages of the production process of SG cast irons. This information becomes useful to determine the affecting chemical elements and which of them are present in the different types of slag commonly found in SG cast iron manufacture. Previous studies ${ }^{6}$ on slag formed in spheroidal and lamellar cast irons have shown that it mostly consists of several oxides as $\mathrm{FeO}, \mathrm{MnO}, \mathrm{SiO}_{2}, \mathrm{Al}_{2} \mathrm{O}_{3}$ and 


\begin{tabular}{|l|ll|}
\hline Journal : Large 40962 & Dispatch : 9-2-2016 & Pages : 14 \\
Article No. : 25 & $\square$ LE & $\square$ TYPESET \\
MS Code : IJMC-D-15-00003 & $\sim_{\text {CP }}$ & $\checkmark$ DSK \\
\hline
\end{tabular}

$81 \mathrm{MgO}$. It has been also reported that these oxides except $82 \mathrm{FeO}$ and $\mathrm{MnO}$ are solid in the melting temperature range. 83 According to the Ellingham's diagram, the formation of 84 these oxides is the result of a balance between the oxi85 dation of such elements and the oxidation of carbon for a 86 given temperature. In accordance with the mentioned 87 literature data, there is a temperature range around $881427^{\circ} \mathrm{C} \quad\left(2600{ }^{\circ} \mathrm{F}\right)-1482{ }^{\circ} \mathrm{C} \quad\left(2700{ }^{\circ} \mathrm{F}\right)$ in which slag 89 formation and the appearance of $\mathrm{CO}$ gas by carbon oxi90 dation on melts are minimal. These authors observed an 91 increase on slag formation temperature when increasing 92 the silicon content for a given carbon content in the melt. 93 The contrary effect was also detected. It is also reported 94 that re-oxidation reactions occur when free-slag melts 95 cool down, so liquid and solid slag compounds can be 96 formed again due to the oxidation of alloying elements 97 present in the liquid cast iron.
In a more recent work ${ }^{7}$, the influence of metallic charge contents on the amount of slag formed and on its chemical composition was studied though any information about the phases involved was not reported. These authors found the lowest amount of slag after melting when high purity pig iron was used as the main constituent of metallic charges. The worst result (highest amount of slag) was found when using foundry returns composed by shot-blasted ferritic ductile iron casting scrap, while intermediate results were obtained when using steel scrap according to its composition and its source. It was also concluded that the composition of the formed slag depends on the metallic charge type. All metallic charge compositions originated a slag type with similar $\mathrm{SiO}_{2}$ and $\mathrm{Al}_{2} \mathrm{O}_{3}$ contents (both were the main oxides) which was obtained from the refractory lining. Slag found when using HPI and steel scrap metallic charges shows relevant amounts of $\mathrm{CaO}$, while $\mathrm{MnO}$ was found on slag obtained from metallic charges that mainly contained foundry returns and steel scrap. Finally, slag formed after melting ductile iron returns showed important $\mathrm{MgO}$ contents. Surprisingly, any contribution on slag composition of silicon content in alloys and of the raw materials cleanliness (this second parameter mainly affected by external oxidation of pig iron) was not found in that

$\mathrm{Katz}^{8}$ showed the harmful effects of Fe-O-bearing slag which promote the oxidation of valuable elements such as $\mathrm{C}$ and $\mathrm{Mn}$. On the other hand, this slag also sticks on the silica refractory which is the most commonly used in electric furnaces. Additions of $\mathrm{SiC}$ in the melting furnace are recommended in this work to avoid this problem. It also reported that such slag sources were sand residues present in the foundry returns and oxidized compounds normally found on raw materials surfaces in case of melting processes made with electric furnaces.

Considering the results of previous studies, two different aims have been approached in this work: the study of the mentioned work. ${ }^{7}$ chemical composition changes and of the different compounds found in slag samples depending on the raw materials used for preparing melts and the minimization of detrimental effects caused by slag which is stuck to the refractory linings.

\section{Experimental Work}

In a first step, six different base melts were prepared in a 6-t capacity medium frequency induction furnace $(250 \mathrm{~Hz}$, $4250 \mathrm{~kW}$ ) using three different metallic charge compositions and two maximum temperatures (see Table 1). In all cases, these raw materials were introduced in the furnace crucible when a remaining amount of melt (around $4000 \mathrm{~kg}$ ) was present in it. The composition of each remaining melt was the one that corresponds to a standard metallic charge previously melted in the furnace (see Table 2). Note that the FeSi alloy was only used with pig iron and steel crap-based charges, while graphite and SiC were exclusively used for preparing the melts with steel scrap. After melting and just after achieving the maximum temperature, an alloy sample and a slag sample were simultaneously extracted from each base melt surface. Then, a second sampling was made after skimming the surface of melts and then remaining them in contact with open air for $45 \mathrm{~min}$ at each of the two selected maximum temperatures. The first and the second groups of samples will be identified as initial (I) samples and as final (F) samples, respectively. These samples have been also identified according to the metallic charge composition (PI for pig iron, FR for foundry returns and SC for steel scrap) and to the maximum temperature achieved during melting process (00 for $1500{ }^{\circ} \mathrm{C}\left(2732{ }^{\circ} \mathrm{F}\right)$ and 45 for $1545^{\circ} \mathrm{C}$ $\left(2813^{\circ} \mathrm{F}\right)$, see Table 1$)$. For instance, the PI00I code is used to identify the samples that have been initially picked up from the base melt prepared with pig iron at $1500{ }^{\circ} \mathrm{C}$ $\left(2732^{\circ} \mathrm{F}\right)$.

In a second step, three slag samples adhered to different refractory linings of the induction furnace have been studied. These samples were removed from the refractory surface at the end of the life span of the furnace linings which duration was not systematically the expected one due to failures on the inductor isolation system. In these cases, the metallic charge composition was commonly used in the manufacturing process of the foundry plant (Table 2) and the melting procedure was similar to the one detailed above. These samples will be identified in the text as UC11, UC31 and UC32 where UC notation refers to "usual charges," the first number is the furnace identification and the second one is the sample number.

In a third step of the present work, a set of experiments were made in order to obtain more information about the formation of slags stuck to the refractory linings. Thus, two different metallic charges, one based on foundry returns and the other one based on steel scrap, were exclusively 


\begin{tabular}{|l|lll|}
\hline Journal : Large 40962 & Dispatch : 9-2-2016 & Pages : 14 \\
& Article No. : 25 & $\square$ LE & $\square$ TYPESET \\
MS Code : IJMC-D-15-00003 & $\square_{\text {CP }}$ & $\checkmark$ DSK \\
\hline
\end{tabular}

Table 1. Temperatures of Melts Prepared in the Induction Furnace and Metallic Charge Compositions (kg)

\begin{tabular}{|c|c|c|c|c|c|c|c|}
\hline Sample & $\mathrm{T} /{ }^{\circ} \mathrm{C}\left({ }^{\circ} \mathrm{F}\right)$ & Pig iron & Steel scrap & Returns & Graphite $^{a}$ & $\mathrm{FeSi}^{\mathrm{b}}$ & $\mathrm{SiC}^{\mathrm{c}}$ \\
\hline PI00I/PI00F & $1500(2732)$ & 1923 & - & - & - & 31 & - \\
\hline FROOI/FROOF & $1500(2732)$ & - & - & 1838 & - & - & - \\
\hline SC00I/SC00F & $1500(2732)$ & - & 1866 & - & 75 & 29 & 19 \\
\hline PI45I/PI45F & $1545(2813)$ & 1966 & - & - & - & 41 & - \\
\hline FR45I/FR45F & $1545(2813)$ & - & - & 1890 & - & - & - \\
\hline SC45I/SC45F & $1545(2813)$ & - & 1838 & - & 67 & 24 & 19 \\
\hline
\end{tabular}

Table 2. Metallic Charge Compositions Used in the Induction Furnace (wt\%)

\begin{tabular}{lllllll}
\hline Sample & Pig iron & Steel scrap & Returns & Graphite $^{\mathrm{a}}$ & $\mathrm{FeSi}^{\mathrm{b}}$ & $\mathrm{SiC}^{\mathrm{c}}$ \\
\hline FR21 & 2.6 & 30 & 65 & 1.2 & 0.2 & 0.5 \\
SC31 & 3.0 & 65 & 28 & 2.6 & 1.0 & 0.7 \\
Usual charge (UC) & 2.5 & 37 & 59 & 1.4 & - & 1.0 \\
\hline
\end{tabular}

a Carbon content: $99.9 \mathrm{wt} \%$

${ }^{\text {b }}$ FeSi composition: 75.2 wt $\%$ Si, 0.7 wt $\%$ Al and 0.3 wt $\%$ Ca

c SiC composition: $65 \mathrm{wt} \% \mathrm{Si}, 25 \mathrm{wt} \% \mathrm{C}$ and $0.8 \mathrm{wt} \% \mathrm{Al}$

187 used for preparing all the base melt batches during the 188 whole life span of each refractory lining in the furnace. 189 Table 2 shows the composition of these two metallic 190 charges which were introduced in the furnace with around $1914000 \mathrm{~kg}$ of remaining melt except in the first charge where 192 the furnace was empty. In all cases, the maximum tem193 perature achieved during the melting process was $1500{ }^{\circ} \mathrm{C}$ $194\left(2732^{\circ} \mathrm{F}\right)$. After finishing the life span of these two 195 refractory linings, a slag sample was obtained from each 196 one for later characterization. These two slag samples are 197 identified as FR21 and SC31 where FR and SC notations 198 refer to foundry returns or to the steel scrap-based charges, 199 respectively. The first number is the furnace identification, 200 and the second one is the sample number.

201 Chemical compositions of melts were determined on 202 samples picked up from the prepared alloys during slag 203 sampling. These analyses were performed using a com204 bustion technique (LECO CS200) for carbon and sulfur and 205 spark emission spectroscopy (ARL Metal Analyzer 206 Iron + Steel) for the rest of elements.

207 X-ray fluorescence (XRF), X-ray diffraction analysis 208 (XRD) and scanning electron microscopy (SEM) and EDS 209 microanalysis were used for characterizing the slag sam210 ples. The first technique was used to determine chemical 211 compositions of slag. Thus, samples were crushed and then 212 were burned at $950{ }^{\circ} \mathrm{C}\left(1742{ }^{\circ} \mathrm{F}\right)$ for $24 \mathrm{~h}$ to remove any 213 remaining amount of carbon and/or sulfur. Then, $0.15 \mathrm{~g}$ of 214 calcined sample was mixed with $5.7 \mathrm{~g}$ of lithium tetraborate (1/40 dilution) and $5 \mathrm{mg}$ of lithium iodide as surfactant factor was finally added to the mixture. This mixture was melted at $1100{ }^{\circ} \mathrm{C}\left(2012{ }^{\circ} \mathrm{F}\right)$ in an induction furnace (Perle'X-3) to obtain the $30 \mathrm{~mm}$ (1.18 inches) in diameter pearls for XRF analysis. The fluorescence intensity was measured with a AXIOS Advanced wavelength dispersion X-ray sequential spectrophotometer equipped with a semiquantitative software program for elements with atomic number higher than $9(\mathrm{~F})$, using as excitation source a tube with a Rh anode. The quantification of the elements is done using a calibration line previously made with international reference geological samples pearl (dilution 1/40) to analyze their chemical composition by XRF.

XRD was used to characterize the constituent phases formed on each slag sample by means of a PANalytical X'Pert PRO MPD q/q Bragg-Brentano powder diffractometer $240 \mathrm{~mm}$ (9.45 inches) in radius. The slag samples were crushed in an agate mortar until micrometer size. Then, the sample was placed in a rectangular standard holder $20 \mathrm{~mm}$ ( 0.79 inches) in length, $15 \mathrm{~mm}$ (0.59 inches) in width and $1 \mathrm{~mm}$ (0.04 inches) in height in order to obtain a flat surface by manual pressing of the powder material using a glass plate.

Scanning electron microscopy and EDS microanalysis (SEM-EDS) were used to corroborate the results obtained from the two other techniques and to check the slag samples' microstructure. For this purpose, the raw samples were broken in small pieces and then were embedded in 


\begin{tabular}{|l|lll|}
\hline Journal : Large 40962 & Dispatch : 9-2-2016 & Pages : 14 \\
& Article No. : 25 & $\square$ LE & $\square$ TYPESET \\
MS Code : IJMC-D-15-00003 & $\square_{\text {CP }}$ & $\checkmark$ DSK \\
\hline
\end{tabular}

243 epoxy resin at room temperature. After conditioning the 244 embedded samples for metallographic inspection, they 245 were sputtered with carbon and then analyzed using a 246 ESEM Quanta 200 FEI, XTE 325/D8395 with observa247 tion conditions of $\mathrm{AV}=20.00 \mathrm{kV}, \quad \mathrm{WD}=10 \mathrm{~mm}$ 248 (0.39 inches) and intensity probe of $4.5 \mathrm{nA}$. Secondary 249 electron mode (SE Image) and backscattered electron mode 250 (BSE Image) were also used for characterizing the slag 251 samples.
The results obtained from the XRF analyses performed on the twelve slag samples collected from base irons can be seen in Table 4. In this table, only those values higher than $1.00 \mathrm{wt} \%$ are shown. The results indicate that silicon oxide is the main constituent of all these samples. Thus, $\mathrm{SiO}_{2}$ is shown to be the most important oxidation product in melts as silicon is the main alloying element and this element exhibits a high tendency to be oxidized. As can be expected, the four slag samples obtained from the melt prepared using foundry returns show the highest $\mathrm{SiO}_{2}$ contents (Table 4) due to the sand adhered to these raw materials and owing to the high silicon content found on the corresponding base melts (see Table 3). The $\mathrm{SiO}_{2}$ content is also higher in the slag samples extracted after 45 min than in those collected just after melting. This result could be related to the progressive oxidation of silicon while keeping melts in the furnace at a given temperature. However, a similar effect due to the use of high temperatures has not been detected.

The aluminum oxide content in the slag samples obtained from the two steel scrap-based melts is higher than the ones extracted from the pig iron-based melts. Although the exclusive $\mathrm{SiC}$ addition made when preparing the steel scrap-based melt can be related to this fact, another important available source of aluminum can be the own steel scrap. The $\mathrm{Al}_{2} \mathrm{O}_{3}$ content is also higher in the samples obtained from melts that were remaining in the furnace than the ones obtained just after melting the metallic charges. This is probably due to the progressive oxidation of aluminum present in the liquid alloy during the remaining time. The high $\mathrm{CaO}$ levels found in the slag samples collected from the melts prepared using steel scraps and pig iron can be explained by the addition of the FeSi ferroalloy. Clear tendencies when comparing the chemical compositions of the slag samples obtained at $1500{ }^{\circ} \mathrm{C}$ $\left(2732{ }^{\circ} \mathrm{F}\right)$ or at $1545^{\circ} \mathrm{C}\left(2813{ }^{\circ} \mathrm{F}\right)$ are not observed.

The XRD analyses carried out on all the slag samples studied in the present work support the results obtained by XRF. Floating slags generated in the induction furnace are mainly composed by amorphous phases. The two main phases with crystalline structures that have been found on these samples are quartz and cristobalite $\left(\mathrm{SiO}_{2}\right)$. Quartz is the stable phase at temperatures lower than $867^{\circ} \mathrm{C}$

Table 3. Chemical Compositions of the Base Melts Prepared in the Present Work (wt\%)

\begin{tabular}{llllllllll}
\hline Samples & $\mathrm{C}$ & $\mathrm{Mn}$ & $\mathrm{Si}$ & $\mathrm{S}$ & $\mathrm{Mg}$ & $\mathrm{Al}$ & $\mathrm{Ti}$ & $\mathrm{Ce}$ & $\mathrm{Zn}$ \\
\hline PI00I/PI00F & 3.90 & 0.18 & 2.02 & 0.020 & 0.002 & 0.0020 & 0.024 & 0.0018 & 0.079 \\
FR00I/FR00F & 3.83 & 0.22 & 2.12 & 0.011 & 0.003 & 0.0029 & 0.023 & 0.0019 & 0.081 \\
SC00I/SC00F & 3.79 & 0.29 & 1.97 & 0.014 & 0.002 & 0.0091 & 0.021 & 0.0024 & 0.199 \\
PI45I/PI45F & 3.98 & 0.18 & 1.78 & 0.021 & 0.002 & 0.0021 & 0.021 & 0.0021 & 0.091 \\
FR45I/FR45F & 3.85 & 0.20 & 1.98 & 0.014 & 0.003 & 0.0029 & 0.024 & 0.0024 & 0.107 \\
SC45I/SC45F & 3.76 & 0.21 & 1.82 & 0.014 & 0.003 & 0.0066 & 0.031 & 0.0023 & 0.218 \\
\hline
\end{tabular}




\begin{tabular}{|l|lll|}
\hline Journal : Large 40962 & Dispatch : 9-2-2016 & Pages : 14 \\
& Article No. : 25 & $\square$ LE & $\square$ TYPESET \\
MS Code : IJMC-D-15-00003 & $\square_{\text {CP }}$ & $\checkmark$ DSK \\
\hline
\end{tabular}

Table 4. Chemical Composition of Floating Slag Samples Analyzed by XRF (wt\%)

\begin{tabular}{llrrrrrrr}
\hline Samples & $\mathrm{SiO}_{2}$ & $\mathrm{Al}_{2} \mathrm{O}_{3}$ & $\mathrm{MgO}$ & $\mathrm{CaO}$ & $\mathrm{Fe}_{2} \mathrm{O}_{3}$ & $\mathrm{MnO}^{2}$ & $\mathrm{ZnO}$ & $\mathrm{CeO}_{2}$ \\
\hline PI00I & 56.90 & 5.83 & 2.51 & 7.31 & 20.26 & 3.27 & - & - \\
PI00F & 63.21 & 10.16 & 3.45 & 6.29 & 3.70 & 2.38 & - & - \\
FR00I & 59.40 & 4.68 & 3.92 & 2.73 & 21.11 & 4.12 & 1.55 & - \\
FR00F & 76.60 & 7.26 & 5.16 & 3.11 & 1.22 & 1.24 & - & - \\
SC00I & 50.99 & 6.59 & 3.95 & 3.10 & 8.53 & 2.47 & 1.43 & - \\
SC00F & 61.37 & 18.72 & 5.72 & 4.34 & 2.46 & 1.80 & 1.45 & - \\
PI45I & 64.14 & 6.33 & 1.97 & 12.83 & 7.08 & 4.66 & - & - \\
PI45F & 62.46 & 10.31 & 3.34 & 8.16 & 8.17 & 2.02 & 1.07 & - \\
FR45I & 69.90 & 8.02 & 10.54 & 3.36 & 1.19 & 1.56 & - & 1.88 \\
FR45F & 68.72 & 8.17 & 9.58 & 3.74 & 2.04 & 1.21 & - & 1.68 \\
SC45I & 41.59 & 9.59 & 10.51 & 12.86 & 9.15 & 1.15 & - & 1.01 \\
SC45F & 56.74 & 21.65 & 7.07 & 4.32 & 3.05 & 1.91 & 1.89 \\
\hline
\end{tabular}

$\left(1593{ }^{\circ} \mathrm{F}\right)$, tridymite is the stable phase from $867^{\circ} \mathrm{C}$ $\left(1593{ }^{\circ} \mathrm{F}\right)$ to $1470{ }^{\circ} \mathrm{C}\left(2678{ }^{\circ} \mathrm{F}\right)$, while cristobalite is the stable phase at higher temperatures above this value. The tridymite phase is not present in the slag samples studied in the present work because is more frequent the crystallization of the cristobalite than the tridymite due to the absence of the tridymite stabilizer oxides. ${ }^{9}$

The other oxides detected in the XRF analyses but not found as crystalline phases by XRD are contained in the mentioned amorphous part of the slag. Two micrographs included in Figure 1 show how the $\mathrm{SiO}_{2}$ crystals grow in the amorphous matrix of the FR45I and FR45F slag samples. The SEM observation of these crystalline phases shows dendritic-type morphologies typically found on phases that nucleate and grow from the liquid alloy.

In addition to the main $\mathrm{SiO}_{2}$ phases, minor amounts of some silicates and other oxides have been also detected in five of the slag samples analyzed by XRD. Magnesium silicates are found in two of the slag samples obtained from base melts prepared with foundry returns (FR00I and FR45F). In the sample FR45F, a magnesium iron oxide $\left(\mathrm{MgFe}_{2} \mathrm{O}_{4}\right)$ is also found. The presence of these Mg-bearing slag compounds in such samples is related to the use of ductile iron returns as raw materials when preparing the base melts mentioned above. On the other hand, crystalline iron silicate $\left((\mathrm{Fe}, \mathrm{Ca})_{2}\left(\mathrm{SiO}_{3}\right)_{2}\right)$ and iron oxide $\left(\mathrm{Fe}_{2} \mathrm{O}_{3}\right)$ are, respectively, detected on PI00I and PI45F samples, while zinc silicate $\left(\mathrm{Zn}_{2} \mathrm{SiO}_{4}\right)$ is present in the SC45F sample. In this last, zinc oxide $(\mathrm{ZnO})$ and an aluminum zinc oxide $\left(\mathrm{ZnAl}_{2} \mathrm{O}_{4}\right)$ are found too. As expected, the iron silicate is found in a sample obtained from a melt prepared with pig iron (surface oxidation), while the zinc compounds are only detected when galvanized steel scrap is used as raw 1 material during melting. Figure 2 shows the XRD spectrum and indexation of the three crystalline phases found in the FR00I slag sample, i.e., quartz, cristobalite and pigeonite
$(\mathrm{Mg}, \mathrm{Ca}, \mathrm{Fe}) \mathrm{SiO}_{3}$. On the other hand, Figure 3 illustrates the crystalline growth of a silicate-type compound (a) found in the same sample and the results obtained from the SEMEDS microanalysis (b) of such compound.

Besides, some nondissolved particles of $\mathrm{SiC}$ and/or FeSi were detected by XRD on samples obtained from melts prepared using these additives (see Table 1). Subsequent SEM analyses made on such samples confirmed these results.

As it has been stated before, the zinc content both in the prepared melts and in the slag samples extracted after melting becomes high when the steel scrap-based metallic charges are used as the galvanized steel scrap from the automotive industry is the main constituent of these charges. This fact is confirmed by means of the XRD analysis made on the slag samples. Figure 4 shows the XRD diffractogram recorded on the SC45F slag sample where the minor crystalline phases are very easily identifiable even though a high content of amorphous phases is found in this sample. Thus, peaks of $\mathrm{Zn}_{2} \mathrm{SiO}_{4}$ (willemite) and $\mathrm{ZnO}$ are detected in addition to the ones that belong to $\mathrm{ZnAl}_{2} \mathrm{O}_{4}$ (gahnite), the latter only appearing in this slag sample. Although all these zinc-bearing phases have not been detected by SEM analysis because they are present in a very minor amount, the microanalysis made on the amorphous phase of the SC45F slag sample shows a small peak of zinc (this sample contains the highest $\mathrm{ZnO}$ and $\mathrm{Al}_{2} \mathrm{O}_{3}$ contents of all samples analyzed) (see Table 4).

\section{Slags Adhered to the Refractory Lining of Induction Furnaces}

\section{Characterization of Slags (Standard Metallic Charges)}

After emptying and then cooling, the furnace crucible slags adhered to the refractory lining are detected in an area located close to the bottom of the crucible and at $1 / 3$ of its 


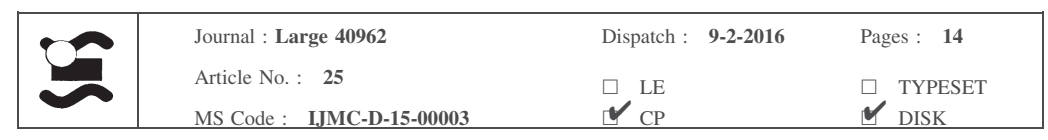

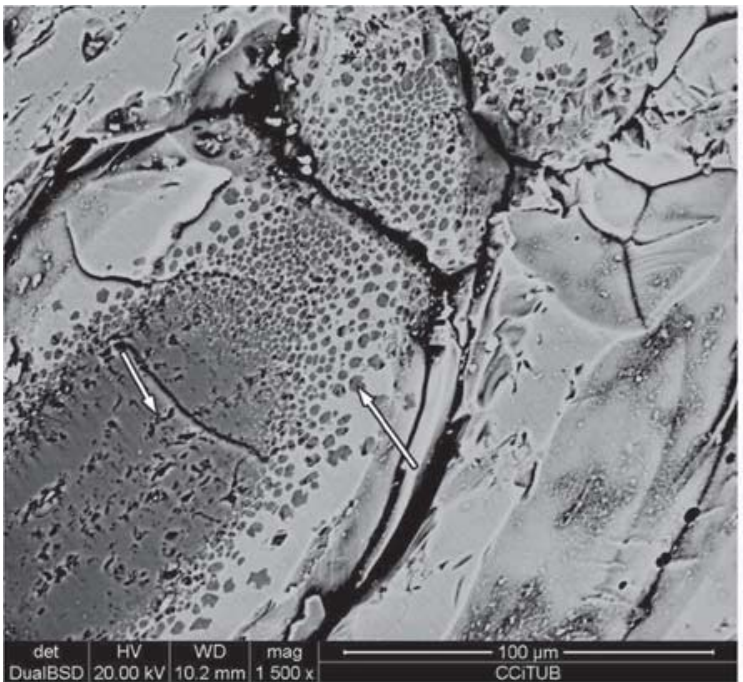

(a)

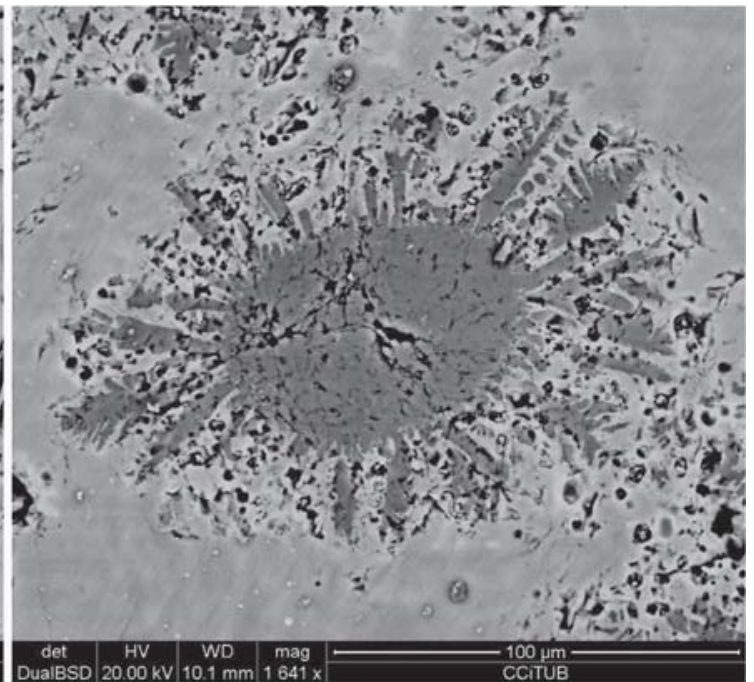

(b)

Figure 1. The $\mathrm{SiO}_{2}$ crystalline phase growing in the amorphous matrix of the FR45I (a) and the FR45F (b) slag samples.

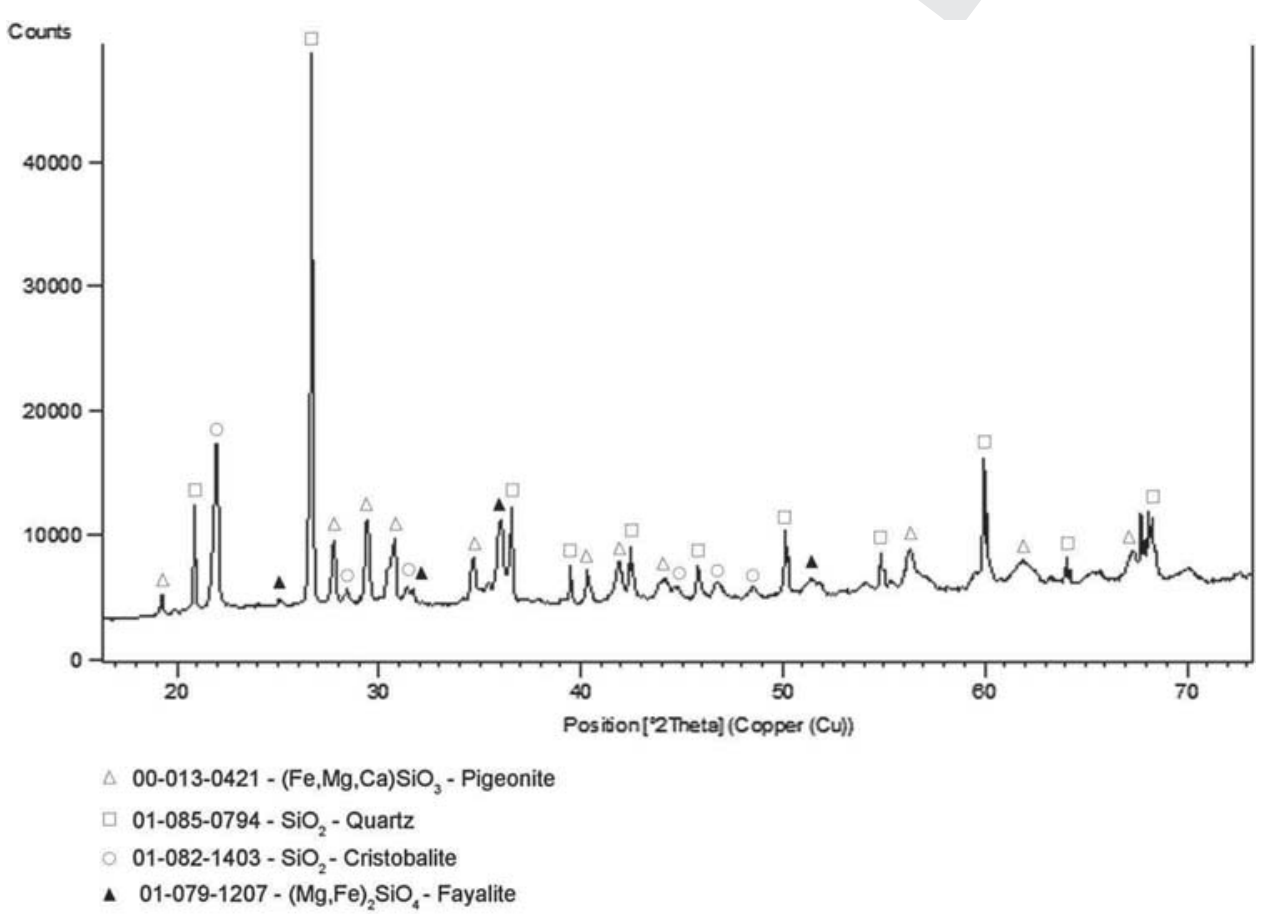

Figure 2. XRD diffractogram and phases indexation on the FROOI sample: quartz, cristobalite and pigeonite $\left[(\mathrm{Mg}, \mathrm{Ca}, \mathrm{Fe}) \mathrm{SiO}_{3}\right]$ were found.

394 total height. This affected area always remains in contact 395 with the liquid alloy even after tapping the furnace 396 according to the usual procedure of the plant. The thickness 397 of the slags found in this affected area ranges from $20 \mathrm{~mm}$ 398 (0.79 inches) to $150 \mathrm{~mm}$ (5.91 inches), and they seem to be 399 heavier than those floating slags directly obtained from 400 melts. Figure 5 shows a general view of a discharged 401 refractory lining of a furnace. The zone marked as 1 in this 402 figure is the worn part of the refractory lining. Notice that the expected thickness of the used refractory lining can be found in the upper levels (marked in Figure 5 with arrows). The adhered slags were found below zone 1, and they affect the whole section of the lining at this lower level (zone 2 in Figure 5).

Quartzite refractory areas in contact with slag showed a darker region with around $1 \mathrm{~cm}$ in thickness which is marked by arrows in Figure 6a. A general view of a slag 


\begin{tabular}{|l|lll|}
\hline Journal : Large 40962 & Dispatch : 9-2-2016 & Pages : 14 \\
& Article No. : 25 & $\square$ LE & $\square$ TYPESET \\
MS Code : IJMC-D-15-00003 & $\square_{\text {CP }}$ & $\checkmark$ DSK \\
\hline
\end{tabular}

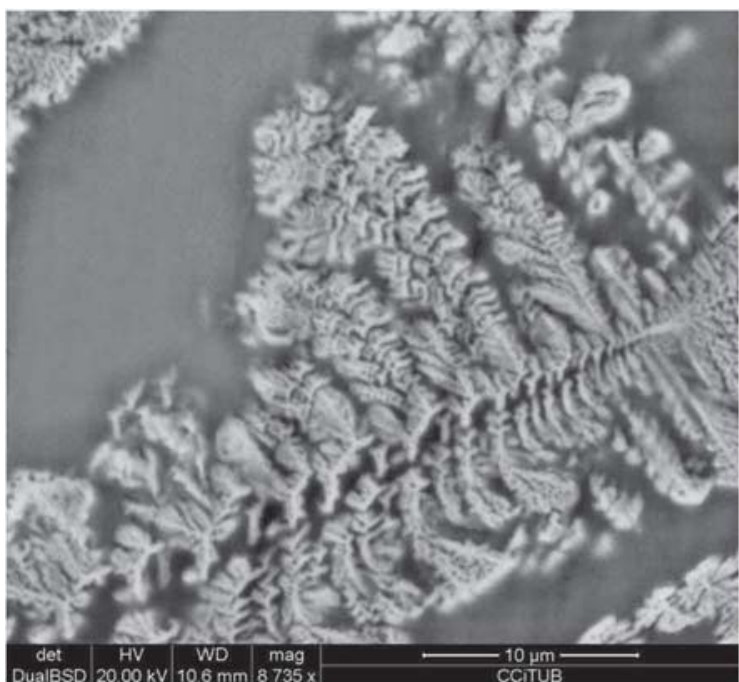

(a)

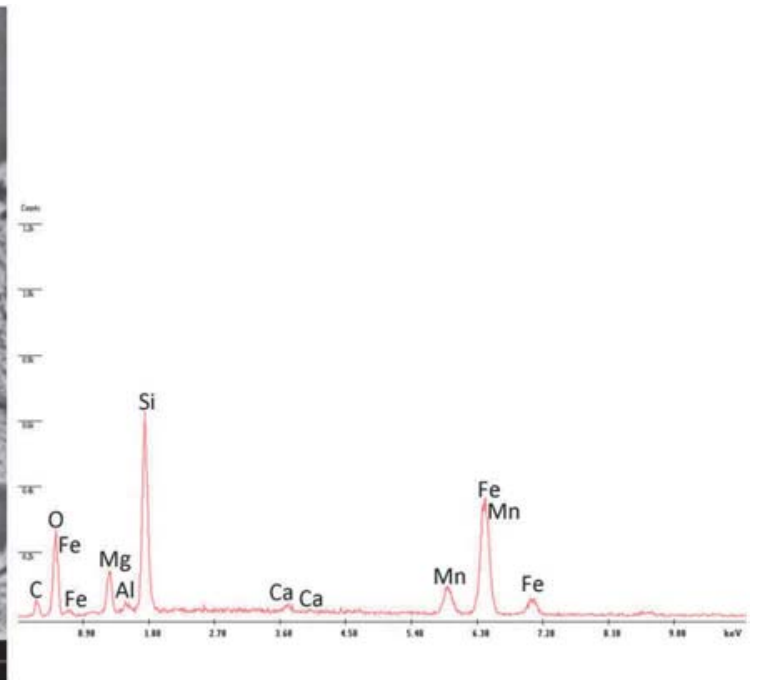

(b)

Figure 3. SEM micrograph showing the crystalline growth of a compound mainly composed by Si and $O$ in the FROOI sample (a) and EDS microanalysis spectrum of the phase observed in the micrograph (b).

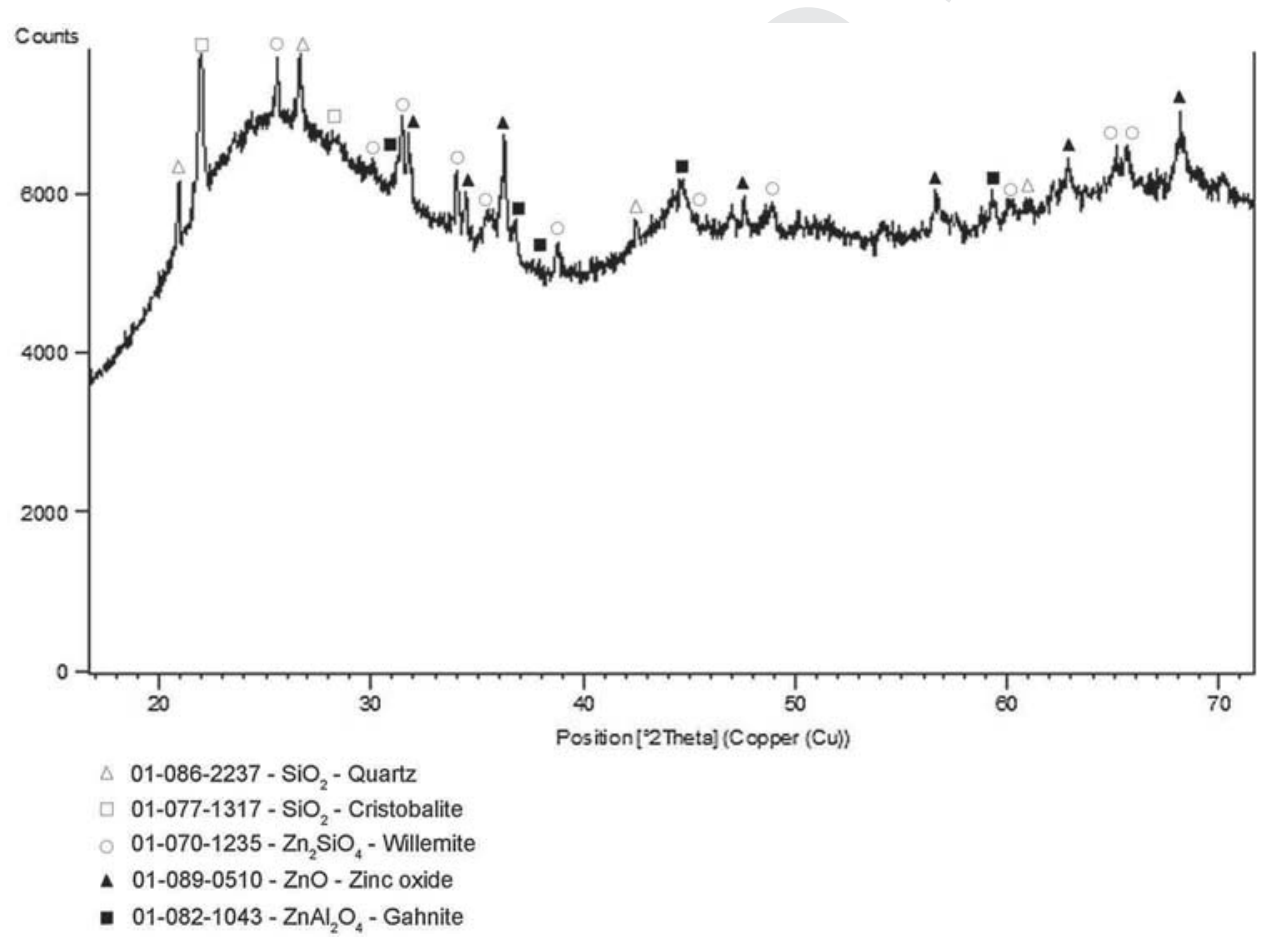

Figure 4. XRD diffractogram of the SC45F slag sample: $\mathrm{ZnO}, \mathrm{Zn}_{2} \mathrm{SiO}_{4}$ and $\mathrm{ZnAl}_{2} \mathrm{O}_{4}$ compounds were found in addition to quartz and cristobalite.

411 that was stuck to the refractory lining is shown in 412 Figure $6 \mathrm{~b}$. Regarding the refractory material, both a free413 slag region and a darker region of a sample were analyzed 414 by SEM-EDS. Only the expected peaks of silicon and 415 oxygen were found for the free-slag region. However, 416 detailed examinations on the darker region revealed the 417 existence of slag penetrations ${ }^{10}$ similar to "veins" (indi418 cated by arrows in Figure $7 \mathrm{a}$ where extra peaks of aluminum, magnesium, calcium and cerium were detected in addition to the peaks of silicon and oxygen (see Figure $7 \mathrm{c}$ ). Most of these further elements found in the darker region are in good agreement with the use of standard metallic charges where returns become the main constituent (Table 2). Here it is worthy to emphasize the relevant intensity of the aluminum peak even though this element does not seem to be the most expectable one 


\begin{tabular}{|llll|}
\hline & Journal : Large 40962 & Dispatch : 9-2-2016 & Pages : $\mathbf{1 4}$ \\
Article No. : 25 & $\square$ LE & $\square$ TYPESET \\
MS Code : IJMC-D-15-00003 & $\checkmark_{\mathrm{CP}}$ & $\checkmark$ DISK \\
\hline
\end{tabular}

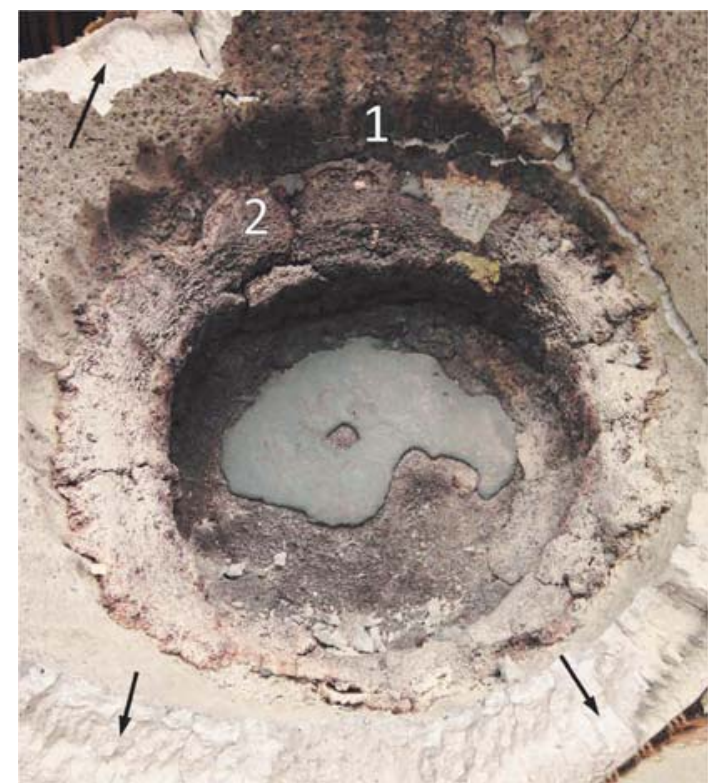

Figure 5. General view of a discharged refractory lining still placed in an induction furnace. Mark 1 indicates the worn away level; mark 2 denotes the slags ring adhered to the refractory. Refractory lining is shown by the arrows.

according to the composition of the standard charges used here. In Figure 7b, a detailed view of a slag vein is also shown which is surrounded by $\mathrm{SiO}_{2}$ grains. These slag penetrations in the refractory areas in contact with adhered slag probably make them darker.

Table 5 shows the chemical composition of the three slag samples that were collected from the discharged refractory linings. In this table, only the oxides with content higher than $1.00 \mathrm{wt} \%$ were included. Surprisingly, all three samples are mainly composed by $\mathrm{Al}_{2} \mathrm{O}_{3}$ and $\mathrm{MgO}$, while $\mathrm{SiO}_{2}$ becomes now a minority oxide when comparing to data include in Table 2. $\mathrm{MgO}$ and $\mathrm{Al}_{2} \mathrm{O}_{3}$ are two of the oxides included in Table 5 with the highest melting point, i.e.,
$>2000{ }^{\circ} \mathrm{C}\left(3632{ }^{\circ} \mathrm{F}\right)$, so they should be more prone to be stuck to the refractory material than the rest of possible oxides. On the other hand, quartzite, i.e., the refractory material used in the present work, is essentially composed by $\mathrm{SiO}_{2}$ which is considered as an acid oxide. Thus, one can expect that the basicity and the amphoteric characteristics of $\mathrm{MgO}$ and $\mathrm{Al}_{2} \mathrm{O}_{3}$, respectively, also become a relevant cause of the reaction between these slags and the refractory material.

The available source of magnesium seems to be the foundry returns used as raw materials; however, the sources of aluminum are numerous. In this second case, possible supplies are the use of additives as ferrosilicon, silicon carbide, the use of steel scraps and also of foundry returns as raw materials. According to this fact and to the high $\mathrm{Al}_{2} \mathrm{O}_{3}$ content found in all the slag samples obtained from the refractory linings, it could be considered that aluminum plays a very relevant role on refractory degradations in electric furnaces and consequently on the life span reduction in these devices. Table 5 also shows important amounts of cerium oxide and lanthanum oxide in these slag samples in comparison with those samples obtained directly from melts. The presence of these two elements should be related to the massive use of foundry returns as raw materials in the melting furnace. Notice that these returns are manufactured with the use of FeSiMg and of inoculants which both contain rare earth elements.

Figure 8 shows a SEM micrograph and the corresponding EDS microanalysis spectra obtained from four different constituents found in the UC11 sample. The microanalysis of the massive phase identified as 1 in this figure led to record peaks of aluminum, magnesium and oxygen in accordance with the results shown in Table 5. Notice that any peak of silicon was not detected in this compound. Another main phase (marked as 2) is composed by a group of elements (calcium, cerium, lanthanum, silicon, sulfur

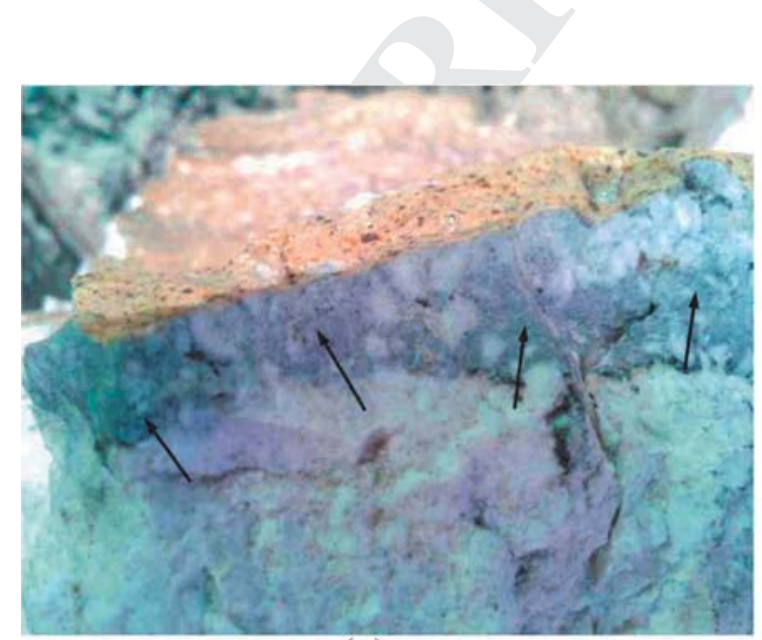

(a)

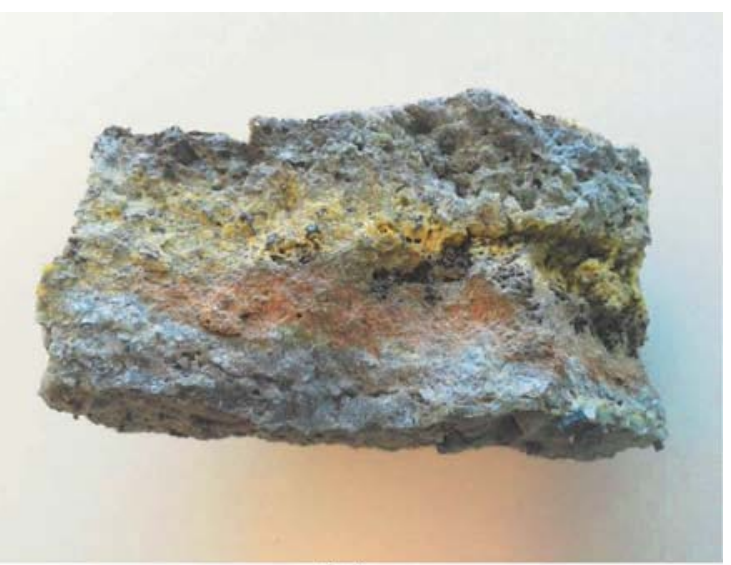

(b)

Figure 6. Detail of the darker areas found in the quartzite refractory lining in contact with slags (a); a general view of a typical slag adhered to the lining (b). 


\begin{tabular}{|l|lll|}
\hline & Journal : Large 40962 & Dispatch : 9-2-2016 & Pages : 14 \\
Article No. : 25 & $\square$ LE & $\square$ TYPESET \\
MS Code : IJMC-D-15-00003 & $\cup_{\text {CP }}$ & $\checkmark$ DISK \\
\hline
\end{tabular}

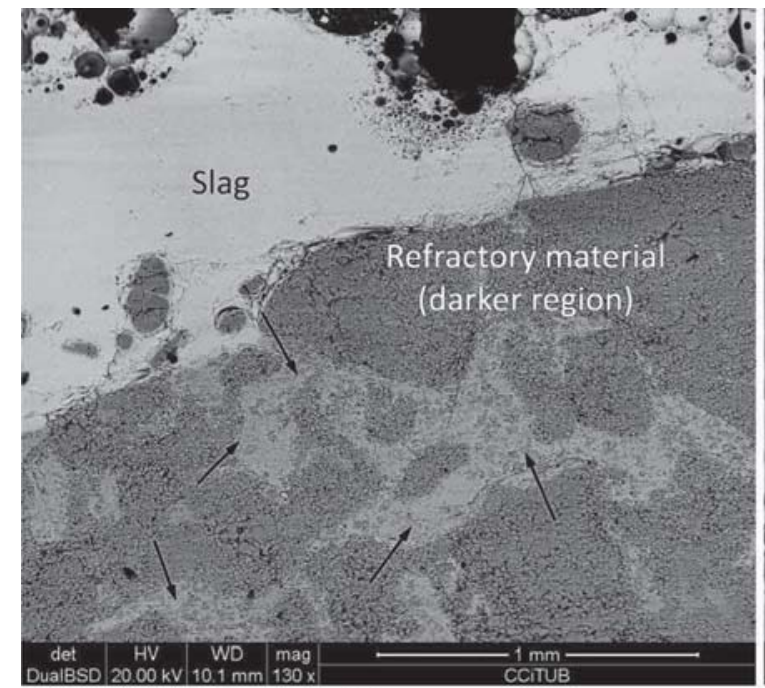

(a)

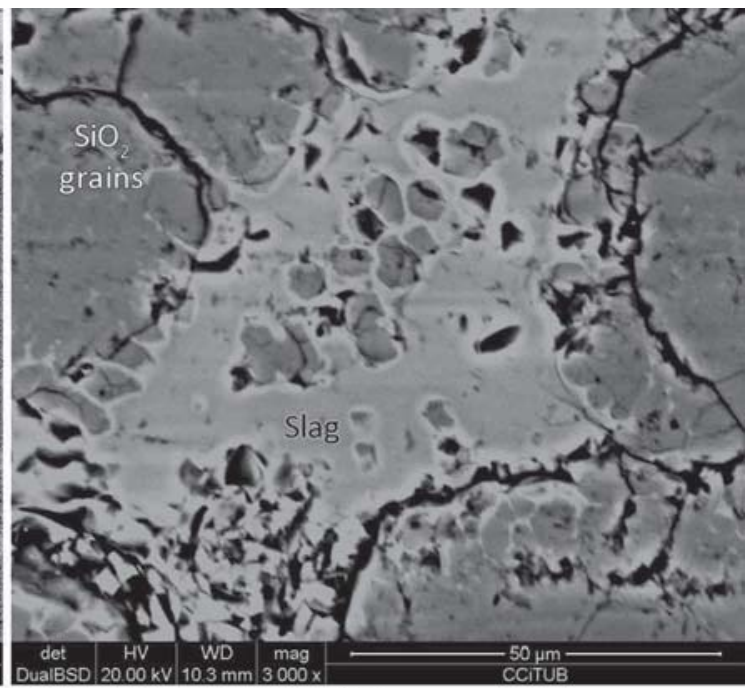

(b)

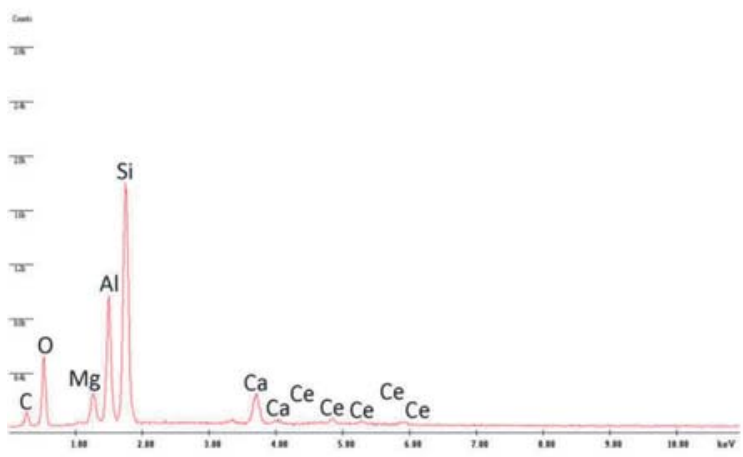

(c)

Figure 7. SEM micrographs of the refractory lining: Showing the slag (light zone) veins by arrows adhered to the darker region (refractory lining) (a); detail of the affected zone of the refractory (b); below the SEM-EDS spectrum of this affected zone is shown (c).

Table 5. Chemical Composition of Slags Stuck to the Refractory Lining Analyzed by XRF (wt\%)

\begin{tabular}{lllllllll}
\hline Sample & $\mathrm{Al}_{2} \mathrm{O}_{3}$ & $\mathrm{MgO}$ & $\mathrm{SiO}_{2}$ & $\mathrm{CeO}_{2}$ & $\mathrm{Fe}_{2} \mathrm{O}_{3}$ & $\mathrm{CaO}$ & $\mathrm{La}_{2} \mathrm{O}_{3}$ & $\mathrm{SO}_{3}$ \\
\hline UC11 & 43.45 & 27.67 & 10.71 & 6.19 & 2.89 & 3.30 & 2.47 & 1.69 \\
UC31 & 61.81 & 24.95 & 5.86 & 2.87 & 1.72 & 1.37 & - & - \\
UC32 & 37.59 & 39.96 & 4.68 & 6.58 & 2.63 & 3.72 & 2.63 & 1.28 \\
\hline
\end{tabular}

and oxygen) which can form complex sulfides and oxides. Finally, peaks of calcium and sulfur (likely to form $\mathrm{CaS}$ ) are present in phase 4 which grew as isolated particles in phase 3 , this latter composed by magnesium, silicon, calcium and oxygen.

The XRD diffractogram shown in Figure 9 was obtained from the UC32 slag sample. It can be seen that it contains a much smaller amount of amorphous phases than the slag samples obtained from the melts surface (see Figure 4). The UC11 and UC31 samples exhibit a similar behavior. This high crystalline degree must be related to the observed heavy aspect of these slags when comparing to the floating ones.

The most important crystalline phase found in the UC32 sample is the $\mathrm{MgAl}_{2} \mathrm{O}_{4}$ (spinel) which is formed by reaction between the two main oxides $\mathrm{MgO}$ and $\mathrm{Al}_{2} \mathrm{O}_{3}$ present in these slags (Table 5). This result confirms the relevant role of aluminum previously predicted in the SEM inspections carried out on the slag-affected regions of refractory (Figure 7). On the other hand, this phase has been also detected in the SEM analysis of the UC11 slag sample shown in Figure 8 (phase 1). The crystalline 


\begin{tabular}{|l|lll|}
\hline Journal : Large 40962 & Dispatch : 9-2-2016 & Pages : 14 \\
& Article No. : 25 & $\square$ LE & $\square$ TYPESET \\
MS Code : IJMC-D-15-00003 & $\square_{\text {CP }}$ & $\checkmark$ DSK \\
\hline
\end{tabular}
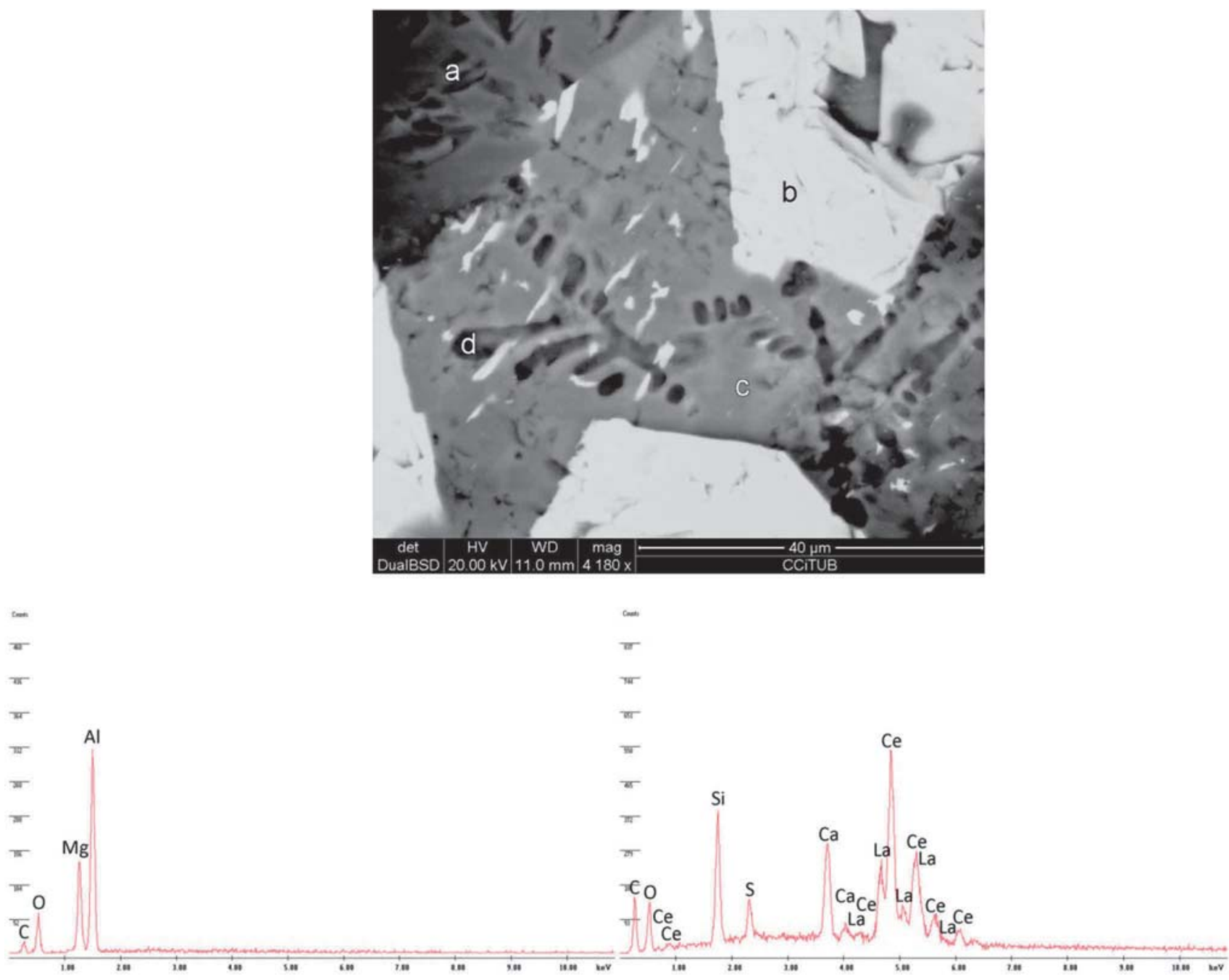

(a)

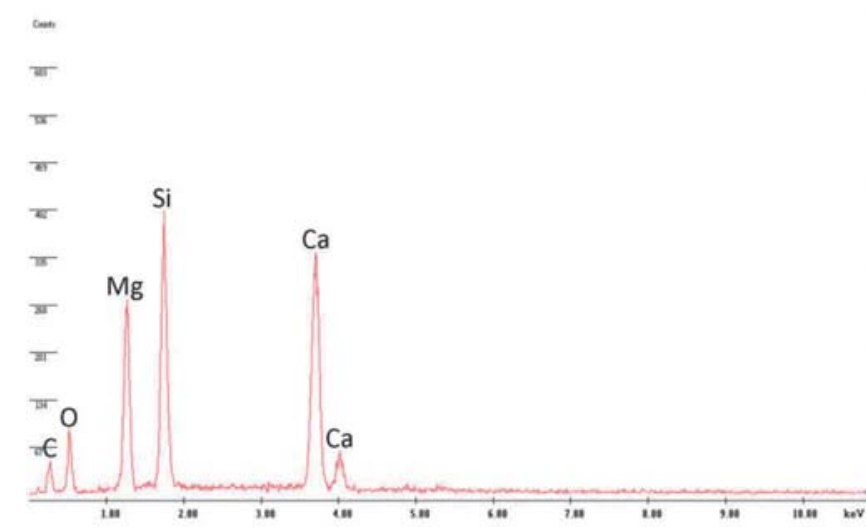

(c) (b)

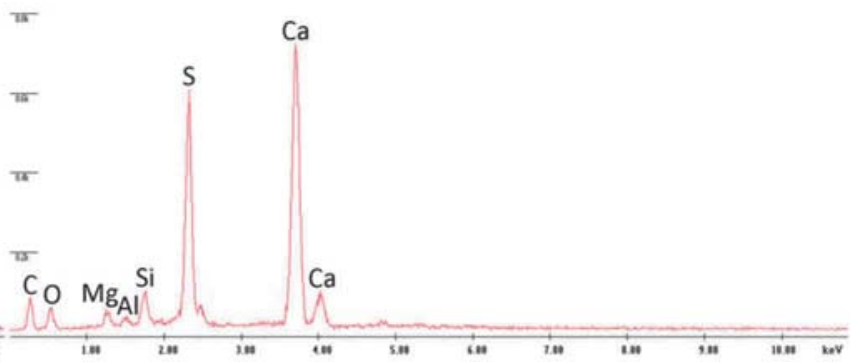

(d)

Figure 8. SEM micrograph of the UC11 slag sample (top). Below the EDS microanalysis spectra of the phases marked on micrograph are shown.

498 phase $\mathrm{MgO}$ (periclase) is also detected in the XRD index-

499 ation shown in Figure 9. This fact indicates that an excess

500 of $\mathrm{MgO}$ which has not reacted with the $\mathrm{Al}_{2} \mathrm{O}_{3}$ to form the

501 spinel is present in the UC32 sample. In fact, this sample showed the highest $\mathrm{MgO}$ content (Table 5). Other minor phases identified in Figure 9 are $\mathrm{CaMgSiO}_{4}$ (monticellite) and $\mathrm{SiO}_{2}$ (quartz). The former compound has been also detected in Figure 8 for the UC11 sample (phase 3). 


\begin{tabular}{|llll|}
\hline & Journal : Large $\mathbf{4 0 9 6 2}$ & Dispatch : 9-2-2016 & Pages : $\mathbf{1 4}$ \\
Article No. : 25 & $\square$ LE & $\square$ TYPESET \\
MS Code : IJMC-D-15-00003 & $\sim_{\text {CP }}$ & $\checkmark$ DSK \\
\hline
\end{tabular}

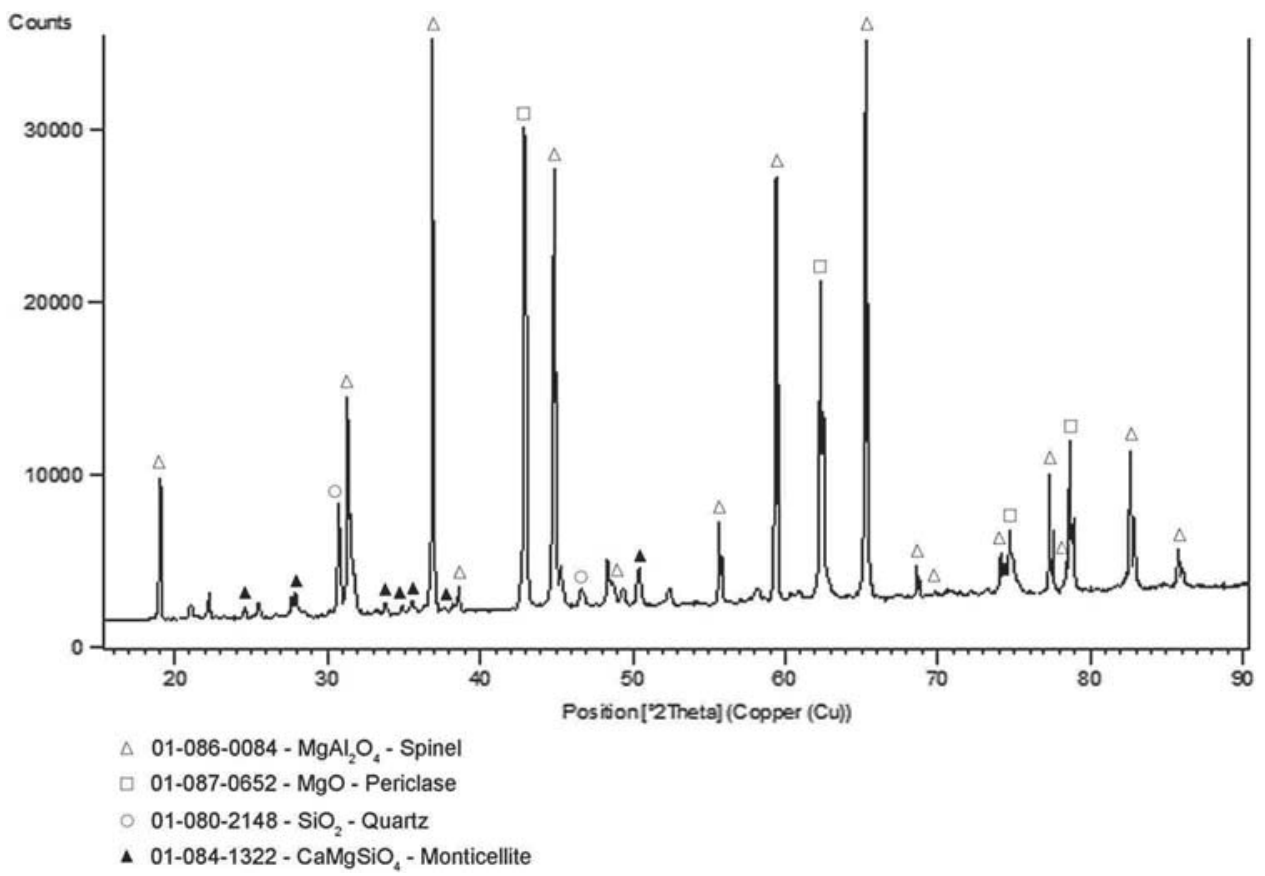

Figure 9. XRD diffractogram of the UC32 slag sample adhered to the refractory lining.

Comparing to the results obtained for the UC32 sample, the XRD characterization of UC11 and UC31 samples also showed a high crystalline degree, $\mathrm{MgAl}_{2} \mathrm{O}_{4}$ (spinel) was detected as the main crystalline phase and $\mathrm{CaMgSiO}_{4}$ (monticellite) and $(\mathrm{Mg}, \mathrm{Fe})_{2} \mathrm{SiO}_{4}$ (forsterite) were identified as minor phases. It is worth nothing that $\mathrm{CaMgSiO}_{4}$ and $\mathrm{CaS}$ compounds had been already detected as phase 3 and phase 4, respectively, in the SEM-ESD analysis performed on the UC11 sample (Figure 8$)$. The $(\mathrm{Mg}, \mathrm{Fe})_{2} \mathrm{SiO}_{4}$ (forsterite) compound which is formed by the reaction between $\mathrm{MgO}$ and $\mathrm{SiO}_{2}$ is only present in the $\mathrm{UC} 11$ slag sample as is shown the highest $\mathrm{SiO}_{2}$ content (Table 5).

\section{Origin of Slags Adhered to Refractory Linings}

Once identified the spinel phase $\mathrm{MgAl}_{2} \mathrm{O}_{4}$ as the main constituent of slags adhered to refractory materials, it is now worthy to investigate the origin of this phase and some of its influencing factors. As it has been described in the experimental section, two different metallic charge compositions (mainly composed by foundry returns or by steel scrap) were separately used during the whole life span of each refractory lining of the furnace following a similar melting procedure. Malfunctions owing to the presence of slag stuck to the refractory lining were detected after 214 melting batches when steel scrap-based charges were only used in the melting furnace. However, no failure occurred after 724 melting batches when exclusively using the return-based charges.

Another important difference is the amount of slags adhered to the refractory linings at the end of their life span. The lining where only steel scrap-based charges were used for melting shows massive slags stuck to the entire refractory ring located in the usual region described above. However, only specific zones of the lining were found to be affected when return-based charges were exclusively used following a similar melting procedure. Thus, it can be concluded that slag formation was more "aggressive" in the first case, based on the use of steel scrap-based charges.

XRF chemical compositions of the two slag samples collected from the linings are shown in Table 6 where only those contents higher than $1.00 \mathrm{wt} \%$ are included. It can be seen that the $\mathrm{MgO}, \mathrm{CeO}_{2}$ and $\mathrm{La}_{2} \mathrm{O}_{3}$ contents are higher for the sample obtained from the return-based charges than for the one coming from the steel scrapbased charges. On the contrary, the $\mathrm{Al}_{2} \mathrm{O}_{3}$ content is much lower in the FR21 sample than in the SC31 sample. These results are expected as foundry returns become a notorious source of the three elements previously mentioned (they were manufactured using a FeSiMg alloy and inoculant), while steel scrap and the adjusting products ( $\mathrm{SiC}$ and $\mathrm{FeSi}$ ) contain significant amounts of aluminum. These auxiliary products should also be considered as the source of $\mathrm{Ca}$ and $\mathrm{Zn}$ in case of the slag sample formed in steel scrap-based melts.

Regarding the phases identified by XRD for these two slag samples, the spinel $\mathrm{MgAl}_{2} \mathrm{O}_{4}$ is the most abundant crystalline phase on the FR21 sample (see the diffractogram shown in Figure 10 below). Additionally, an important amount of $\mathrm{MgO}$ (periclase) has been also found in this sample. The crystalline phases detected on the SC31 


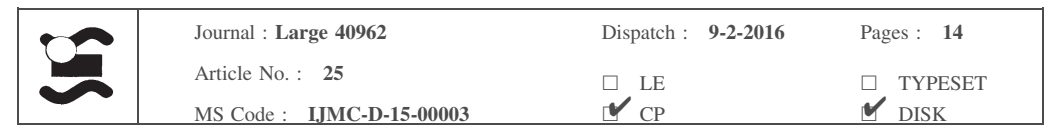

Table 6. Slag Samples Composition Analyzed by XRF (wt\%)

\begin{tabular}{llllllllll}
\hline Sample & $\mathrm{Al}_{2} \mathrm{O}_{3}$ & $\mathrm{MgO}$ & $\mathrm{SiO}_{2}$ & $\mathrm{CeO}_{2}$ & $\mathrm{Fe}_{2} \mathrm{O}_{3}$ & $\mathrm{CaO}$ & $\mathrm{La}_{2} \mathrm{O}_{3}$ & $\mathrm{SO}_{3}$ & $\mathrm{ZnO}$ \\
\hline FR21 & 30.17 & 36.56 & 8.69 & 9.29 & 2.79 & 4.29 & 3.78 & 2.15 & - \\
SC31 & 60.61 & 7.48 & 16.66 & 1.16 & 4.60 & 6.28 & - & - & 1.13 \\
\hline
\end{tabular}

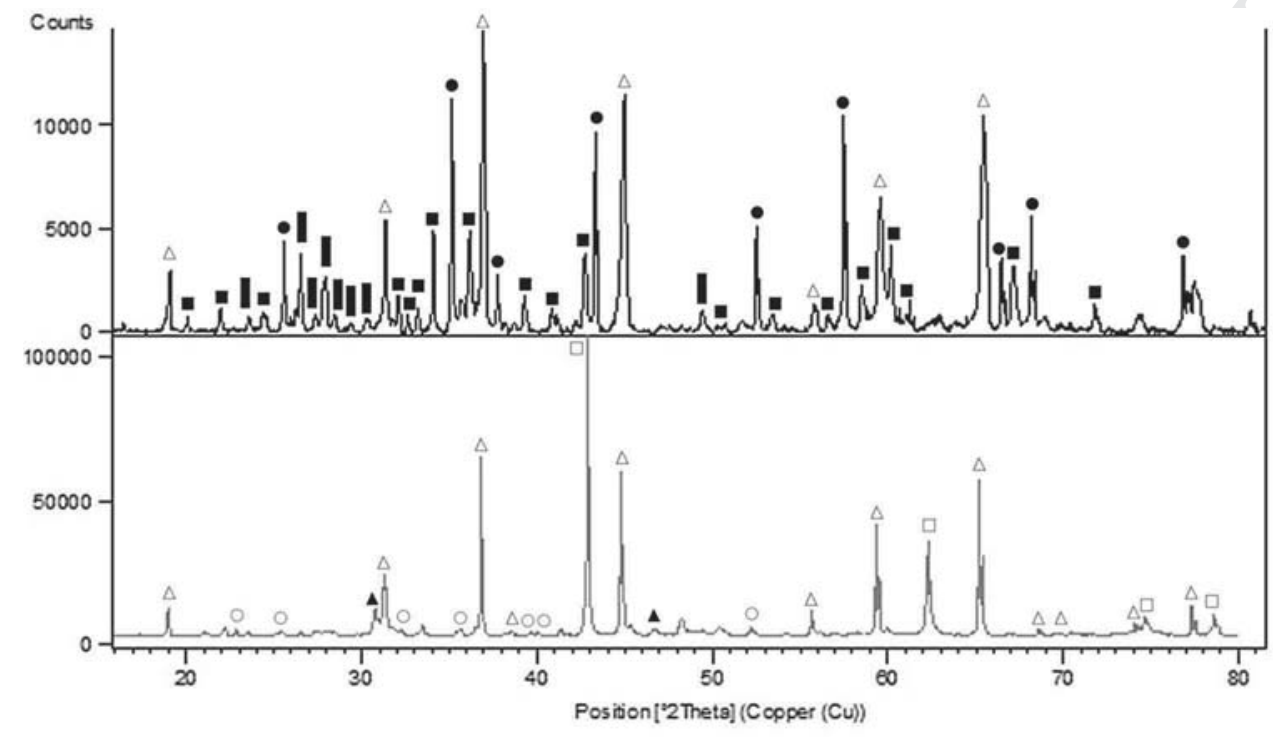

$\triangle$ 01-077-1203- $\mathrm{MgAl}_{2} \mathrm{O}_{4}-$ Spinel

$\square$ 01-089-4248 - MgO - Periclase

01-077-1028 - (Mg,Fe) $)_{2} \mathrm{SiO}_{4}$ - Forsterite
A 01-080-2148- $\mathrm{SiO}_{2}-$ Quartz

- 01-076-0665- $\mathrm{CaO}\left(\mathrm{Al}_{2} \mathrm{O}_{3}\right) 6$ - Hibonite

- 01-075-1864- $\mathrm{Al}_{2} \mathrm{O}_{3}$ - Aluminum Oxide

\01-089-1471 - $\mathrm{Ca}\left(\mathrm{Al}_{2} \mathrm{Si}_{2} \mathrm{O}_{8}\right)$ - Anorthite

Figure 10. XRD diffractogram and indexation of: the SC31 sample (above) and the FR21 sample (below).

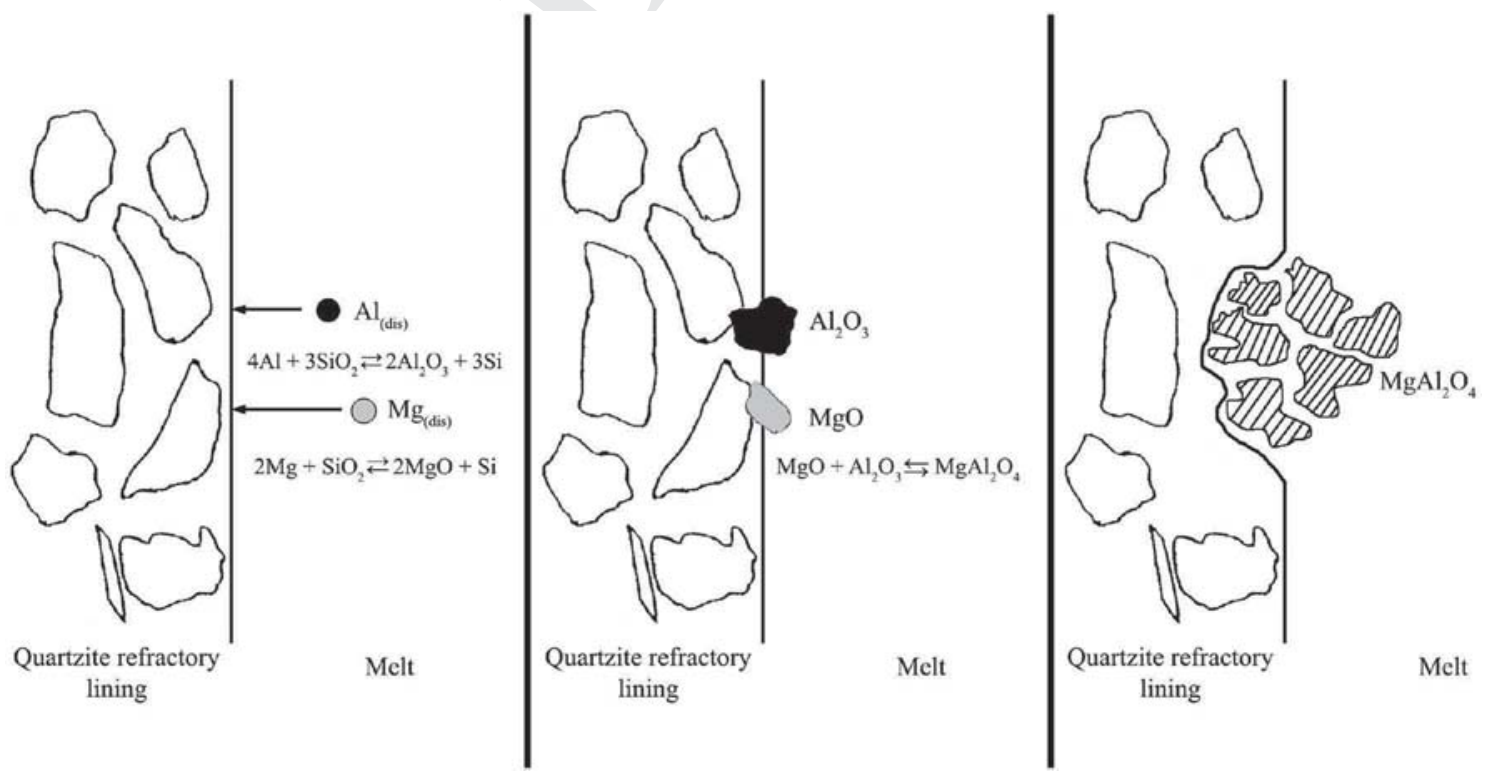

Figure 11. Schema of the steps proposed for the adhered slags formation in the quartzite refractory linings. 


\begin{tabular}{|l|lll|}
\hline Journal : Large 40962 & Dispatch : 9-2-2016 & Pages : 14 \\
& Article No. : 25 & $\square$ LE & $\square$ TYPESET \\
MS Code : IJMC-D-15-00003 & $\square_{\text {CP }}$ & $\checkmark$ DSK \\
\hline
\end{tabular}

564 sample are quite different (Figure 10 above). In this case,

565

566

567

568

569

570

571

572

573

574

575

576

577

578

579

580

581

582

583

584

585

586

587

588

589

590

591

592

593

594

595

596

597

598

599

600

601

602

603

604

605

606

607

608

609

610

611

612

613

614

many phases that contain aluminum and calcium have been found, being the most relevant the $\mathrm{MgAl}_{2} \mathrm{O}_{4}$ spinel, $\mathrm{Al}_{2} \mathrm{O}_{3}$ (corundum), $\mathrm{CaAl}_{2} \mathrm{Si}_{2} \mathrm{O}_{8}$ (anorthite) and an aluminumcalcium oxide known as hibonite. These XRD outcomes are in good agreement with the differences shown in Table 6, all confirming the negative effect of aluminum on life span of refractory linings.

A scheme that illustrates the mechanism and the probable reactions involved in the formation of slags adhered to the refractory linings is shown in Figure 11. Part of the aluminum dissolved in the melt would react with the quartzite giving aluminum oxide and silicon as final products. Similarly, the magnesium dissolved can react with the refractory material to obtain magnesium oxide and silicon. Thus, these two oxides would be present close to the lining, so they can react to form the spinel $\left(\mathrm{MgAl}_{2} \mathrm{O}_{4}\right)$ previously characterized as the mainly phase of these detrimental slag compounds.

Additional experiments were made using different melting furnaces in order to evaluate the detrimental effect of aluminum coming from $\mathrm{FeSi}$ and $\mathrm{SiC}$ products. Thus, apparently favorable metallic charges composed $58 \%$ foundry returns, $37 \%$ steel crap, $2.5 \%$ pig iron, $1.7 \%$ graphite and $0.8 \% \mathrm{FeSi}$ with a low aluminum content $(0.029 \mathrm{wt} \%)$ and without any $\mathrm{SiC}$ addition were exclusively used during the whole life span of 22 refractory linings. As a result of these experiments, it was observed that slags were adhered to 20 discharged refractory linings, whereas they were not found in the other 2 ones. When SiC was reintroduced again to metallic charges according to the standard composition of charges (Table 2), both the percentage of affected linings and the amount of slags adhered to them slightly increased. These results show the important role of steel scrap as the main aluminum source of melts prepared in the present work.

\section{Conclusions}

Characterization of the slag samples analyzed in the present work has led to know both the chemical and structural differences between slags formed in the upper surface of melts and those adhered to the refractory lining of medium frequency induction furnaces. In this second case, serious malfunctions are normally detected on these devices which force to stop the melting process and finally to replace the refractory lining with important extra costs for foundry plants. The main conclusions of this work are the following:

1. Slags floating in melt surfaces contain high amounts of amorphous constituents probably due to their rapid formation. This fact could explain the vitreous aspect normally found on these slags at room temperature. The majority crystalline phases detected on these floating slags are $\mathrm{SiO}_{2}$ as quartz and cristobalite. The rest of compounds (oxides) detected by XRF and not identifiable by XRD techniques are included in the amorphous fraction of this slags.

2. In general, significant differences have not been detected regarding chemical composition and constituent phases between the slag samples collected just after finishing the melting of metallic charges and the corresponding ones obtained after remaining melts in contact with open air for $45 \mathrm{~min}$. In this sense, only an increase in some oxides as $\mathrm{Al}_{2} \mathrm{O}_{3}$ was found in case of samples from steel scrap-based charges.

3. Floating slags formed when using steel scrapbased charges showed the highest zinc and aluminum contents and they are the only samples where a crystalline phase $\left(\mathrm{ZnAl}_{2} \mathrm{O}_{4}\right.$, gahnite) different than $\mathrm{SiO}_{2}$ was detected by XRD techniques. These high zinc and aluminum contents are due to the use of galvanized steel scrap as raw material ( $\mathrm{Zn}$ and potentially $\mathrm{Al}$ ) and of $\mathrm{FeSi}$ and $\mathrm{SiC}$ as additives (Al). On the other hand, rests of nondissolved additives as $\mathrm{FeSi}, \mathrm{SiC}$ and graphite have been also detected on these samples.

4. In case of slags formed from return-based charges, zinc and aluminum contents are low, while the content of those elements involved in the manufacture of ductile iron castings ( $\mathrm{Mg}, \mathrm{Ce}$ and $\mathrm{La}$ ) becomes comparatively high. The XRD analyses made on these slags revealed the existence of minor amounts of silicates that contain these specific elements in addition to the $\mathrm{SiO}_{2}$ phase.

5. Slags attached to the quartzite refractory lining of the induction furnaces and considered as the more detrimental ones mainly consist of $\mathrm{MgAl}_{2} \mathrm{O}_{4}$ (spinel) which is probably formed by reaction between $\mathrm{Al}_{2} \mathrm{O}_{3}$ and $\mathrm{MgO}$ compounds.

6. Slags adhered to the refractory lining show chemical compositions quite different from those found in floating ones. In the former case, $\mathrm{Al}_{2} \mathrm{O}_{3}$ and $\mathrm{MgO}$ become the most abundant oxides on the samples analyzed and their content depends on the metallic charge composition and on the amount and type of additives used during the melting procedure. It has been demonstrated in the present study that the highest amount of slags stuck to the refractory material were found when a high content of $\mathrm{Al}_{2} \mathrm{O}_{3}$ is present in the slag composition. Thus, aluminum must play a critical role in the detrimental effect of these slags on the life span of refractory linings.

7. It has been checked that those adhered slags with a high $\mathrm{Al}_{2} \mathrm{O}_{3}$ content and considered more "aggressive" against quartzite linings are promoted when using steel scrap-based metallic charges during melting. This result leads to think that steel scrap 


\begin{tabular}{|l|lll|}
\hline & Journal : Large $\mathbf{4 0 9 6 2}$ & Dispatch : 9-2-2016 & Pages : 14 \\
Article No. : 25 & $\square$ LE & $\square$ TYPESET \\
MS Code : IJMC-D-15-00003 & $\cup_{\text {CP }}$ & $\checkmark$ DISK \\
\hline
\end{tabular}

is the most important available source of aluminum though $\mathrm{SiC}$ and $\mathrm{FeSi}$ products have also to be taken into account regarding this sense.

8. Finally, it has been possible to minimize the formation of slags adhered to linings by reducing the aluminum sources in raw materials and additives used in the melting processes. An effective control to keep a proper balance among $\mathrm{MgO}, \mathrm{SiO}_{2}$ and $\mathrm{Al}_{2} \mathrm{O}_{3}$ oxides during melting should be quite helpful to prevent the formation of the $\mathrm{MgAl}_{2} \mathrm{O}_{4}$ spinel phase and consequently of these harmful slags.

\section{Acknowledgments}

This work has been financially supported by Fundería Condals S.A foundry and by Catalan Government by awarding the scholarship from AGAUR for the Industrial $\mathrm{PhD}$. The authors would like to acknowledge scientific and technological centers (CCiT) from the University of Barcelona for the collaboration in all the analysis.

\section{REFERENCES}

1. P.R. Khan, W.M. Su, H.S. Kim, J.W. Kang, J.F. Wallace, AFS Trans. 172, 105-116 (1987)

2. M. Gagné, M.-P. Paquin, P.-M. Cabanne, FTJ, 276-280 (2009)

3. ITP Metal casting, BCS, Incorporated (November 2005)

4. Vivek R. Gandhewar, Satish V. Bansod, Atul B. Borade, IJET 3(4), 277-284 (2011)

5. A. Loizaga, J. Sertucha, R. Suárez, Rev Metal Madrid 44(5), 432-446 (2008)

6. R.W. Heine, C.R. Loper, MOD CAST, 50(3), 155-122 702 (1966) 703

7. C. Labrecque, M. Gagné, E. Planque, Keith Millis 704 Symposium on Ductile Cast Iron (2003) 705

8. S. Katz, AFS Trans., Paper 04-132(05), 2-13 (2004) 706

9. Peter J. Heaney, Rev. Mineral. Geochem. 29, 1-40 707 (1994)

10. W.E. Lee, S. Zhang, Int. Mater. Rev. 44(3), 77-104 709 (1999) 
Journal : 40962

Article : 25

\section{Springer}

\section{Author Query Form}

Please ensure you fill out your response to the queries raised below and return this form along with your corrections

\section{Dear Author}

During the process of typesetting your article, the following queries have arisen. Please check your typeset proof carefully against the queries listed below and mark the necessary changes either directly on the proof/online grid or in the 'Author's response' area provided below

\begin{tabular}{|l|l|l|}
\hline Query & Details Required & Author's Response \\
\hline AQ1 & $\begin{array}{l}\text { Figures 2, 4, 8, 9,10 are poor in quality as it looks fuzzy. Please supply a high-resolution version of the } \\
\text { said figure preferably in .tiff or .jpeg format with 300 dpi resolution. }\end{array}$ & \\
\hline AQ2 & Please provide volume number for reference [2]. & \\
\hline
\end{tabular}

